\title{
PENGEMBANGAN GAME LABU SISWA KELAS VII
}

\author{
Dini Hapsari, Agus Wedi, Sulthoni Sulthoni \\ Jurusan Teknologi Pendidikan, Fakultas Ilmu Pendidikan, Universitas Negeri Malang \\ Jalan Semarang 5 Malang 65145-0341-574700 \\ Email : agus.wedi.fip@um.ac.id
}

\section{Article History}

Received: 23 September 2020, Accepted: 05 Januari 2021, Published: 10 Agustus 2021

\begin{abstract}
Abstrak
Game lapisan bumi (Game LABU) yaitu memodifikasi media belajar IPA menjadi sebuah permainan menyenangkan untuk meningkatkan motivasi belajar siswa. Media belajar mengajar yang dikembangkan yaitu game LABU mata pelajaran Ilmu Pengetahuan Alam (IPA). Tujuan pengembangan game LABU yaitu untuk menghasilkan produk multimedia game LABU siswa kelas VII yang layak diterapkan didalam pembelajaran. Penelitian ini menggunakan metode Lee \& Owens. Penilaian terhadap produk multimedia game LABU yaitu oleh beberapa ahli media dan ahli materi. Uji coba produk game LABU melibatkan 6 siswa kelas VII SMPN 2 Gurah. Simpulan data hasil review produk memperoleh tanggapan positif dalam kategori positif.
\end{abstract}

Keyword: Multimedia, Game LABU, Ilmu Pengetahuan Alam (IPA)

\begin{abstract}
Earth layer game (Game LABU) is modifying science learning media into a fun game to increase student motivation. The teaching and learning media developed is the LABU game for Natural Science (IPA) subjects. The aim of developing the LABU game is to produce a LABU multimedia game product for grade VII students that is feasible to be applied in learning. This study uses the Lee \& Owens method. Evaluation of LABU multimedia game products by several media experts and material experts. The LABU game product trial involved 6 grade VII students of SMPN 2 Gurah. In conclusion, product review data received positive responses in the positive category.
\end{abstract}

Keyword: Multimedia, Pumpkin Game, Natural Sciences (IPA) 


\section{PENDAHULUAN}

Media dalam aktifitas belajar memiliki manfaat untuk memudahkan penggambaran dan penyampaian materi atau informasi yang abstrak, luas, dan sulit dijangkau menjadi lebih menarik. Menurut Dewi dan Wibawa (2017) pembelajaran yang baik dan tepat adalah aktifitas belajar yang kreatif, aktif, inovatif dan menyenangkan. Sesuai perkembangan kemajuan teknologi komunikasi dan tingginya dinamika dalam dunia Pendidikan dituntut untuk mengembangkan media yang lebih kreatif dan bervariasi. Demikian seorang pengajar harus dapat menyesuaikan dengan tuntutan perkembangan teknologi komunikasi. Dalam perkembangannya media dapat digabungkan dengan media yang lain disebut dengan istilah multimedia (Wulandari, dkk. 2016). Pada dasarnya, multimedia menyajikan satu jenis media bahkan lebih untuk penyampaian informasi (Munir, 2013). Perpaduan antara beberapa media baik berupa teks, video, suara, animasi, maupun gambar yang dikombinasi sedemikian rupa secara digital disebut dengan multimedia.

Berdasarkan hasil wawancara guru IPA di SMPN 2 Gurah diperoleh informasi bahwa metode belajar yang diterapkan saat ini adalah metode konvensional, diskusi dan eksperimen. Diketahui pula bahwa penyampaian materi memanfaatkan buku paket siswa kelas VII dan sesekali melakukan praktek atau eksperimen pada beberapa materi. Meskipun sarana teknologi yang tersedia di sekolah tersebut sangat mendukung, pemanfaatan sarana teknologi untuk mendukung kegiatan belajar mengajar belum dilakukan secara penuh. Pendidik juga memaparkan bahwa hasil tes hasil belajar siswa masih banyak yang belum mencapai kriteria yang ditentukan. Selanjutnya dilakukan wawancara terhadap beberapa siswa kelas VII, siswa menjelaskan bahwa selama ini belum pernah menggunakan media apapun baik media video, media tutorial, maupun game dalam proses pembelajaran. Siswa mengatakan mengalami kesulitan dalam memahami materi, salah satunya materi "Lapisan Bumi" meskipun sudah ditunjang dengan buku paket pegangan setiap siswa. Kompetensi yang harus dicapai siswa pada materi lapisan bumi yaitu siswa mampu memahami lapisan bumi, gempa bumi, gunung api, dan tindakan pengurangan resiko sebelum, saat terjadi, dan setelah terjadi. Siswa pun mengaku bosan dengan metode yang diterapakan guru.

Hakim (2016) berpendapat bahwa presentase menunjukkan angka mencapai 60\% terhadap ketuntasan indikator pembelajaran dengan media animasi interaktif karena pebelajar berperan pasif, hanya indera penglihatan dan pendengaran yang berperan dominan. Selain itu menurut Baddeley (2010) dalam teori Working Memory, informasi verbal dan visual apabila tidak ditampilkan secara simultan maka ingatan yang diserap hanya bertahan dalam jangka waktu yang pendek, sedangkan informasi verbal dan visual ditampilkan secara simultan maka ingatan yang diserap dapat bertahan dalam waktu yang lebih panjang. Berdasarkan penjelasan diatas, maka diperlukan suatu media dalam aktifitas belajar untuk memvisualisasikan materi yang abstrak. Masalah diatas dapat ditangani dengan pemanfaatan multimedia dalam aktifitas belajar mengajar dengan multimedia.

Pemanfaatan media menurut Danim (2008) bahwa dalam aktifitas belajar mengajar perlu adanya teknologi sebagai alat bantu aktivitas belajar mengajar didalam kelas, terlebih peningkatan dalam capaian hasil belajar siswa. Pemakaian media dengan tepat, baik dan bervariasi dapat menurunkan tingkat kejenuhan siswa dalam aktifitas belajar dan membantu menerima materi dengan mudah. Berdasarkan uraian diatas multimedia cocok dimanfaatkan dalam aktifitas belajar mengajar guna peningkatan kualitas dan kuantitas belajar siswa. Sejalan dengan hasil penelitian Bire, dkk. (2014) bahwa aktifitas belajar mengajar menggunakan gaya belajar visual, auditorial serta kinestetik secara bersamaan berdampak positif terhadap hasil capaian belajar siswa.

Dari beberapa jenis multimedia yang ada, salah satu media yang dikemas seperti halnya permainan ialah game edukasi. Menurut Dasar (2009) permainan yang disusun guna meningkatkan konsentrasi, daya pikir dan menyelesaikan masalah adalah game. Dalam artikel Rohwati (2012) tentang pengaruh pemanfaatan game didalam kelas, bahwa pemanfaatan game nuansa belajar baik 
secara teoritis maupun empiris dalam aktifitas belajar mengajar dapat memperbaiki hasil belajar siswa. Penelitian oleh Maktifitas belajar mengajarelero, dkk. (2014) memaparkan bahwa aktifitas belajar mengajar berbasis game memberikan dampak positif terhadap kinerja dan motivasi siswa. Maka pemanfaatan game mulai dimanfaatkan sebagai media dalam aktifitas belajar. Selain itu menurut (Surahman \& Surjono: 2017; Surahman \& Alfindasari; 2018) media mobile learning dalam aktifitas belajar mengajar dapat menambah motivasi belajar siswa.

Dari paparan diatas, media berupa game dapat menjadi media dalam aktifitas belajar mengajar dapat mempermudah siswa menerima materi, dikemas seperti halnya permainan semenarik mungkin, serta menyenangkan bagi pebelajar sehingga mengurangi rasa jenuh atau bosan dalam belajar. Media berupa game dimanfaatkan sebagai sumber belajar secara mandiri tanpa adanya guru. Dengan demikian, State of the art yang dilakukan adalah mengembangkan produk multimedia game LABU untuk siswa kelas VII yang layak digunakan dalam aktifitas belajar, meningkatkan hasil belajar dan motivasi belajar siswa. Produk dirancang untuk pebelajar kelas VII guna hasil belajar yang lebih memuaskan, sehingga ilmu yang didapat menjadi dasar pemahaman ilmu pengetahuan dijenjang berikutnya. Dengan adanya media pengembangan berupa game LABU siswa kelas VII dapat menjadi variasi media belajar unik dan menarik sehingga pebelajar lebih mudah menerima materi yang dipelajari.

\section{METODE}

Game dikatakan media belajar yang disusun sesuai tujuan yang dicapai untuk membantu aktifitas belajar menjadi lebih praktis (Royle, 2008). Sedangkan menurut Wolf (2000) game nuansa belajar yaitu permainan dengan tujuan menyampaikan informasi (materi belajar) dengan unsur pemberian nilai (scoring), waktu, dan umpan balik didalamnya. Ramadhan, dkk (2019) mengatakan bahwa game nuansa belajar adalah sebuah aplikasi permainan yang berisi materi-materi yang mendidik. Samsul (2016) juga mengatakan bahwa perlu adanya motivasi dan tantangan dalam sebuah game sehingga menarik untuk dioperasikan. Dapat diartikan pula, game edukasi merupakan suatu pemanfaatan media untuk memberikan materi dan menambah ilmu pengetahuan melalui sebuah media yang menarik, unik, dan menyenangkan. Dalam rancangan game LABU yang baik dan tepat diharuskan memenuhi kriteria game edukasi. Dalam pengembangannya perlu menerapkan elemen-elemen game, seperti tujuan dan objek, aturan, tantangan, outcomes dan umpan balik, interaksi, dan alur cerita (Prensky, 2001). Dari 6 kriteria yang harus dipenuhi untuk merangcang game dengan tujuan membuat siswa belajar dalam kondisi senang dan tidak mudah terlupakan, memasukkan informasi atau teori dan menghubungkan pengetahuan. Sesuai pernyataan Alessi \& Trollip (2001) bahwa ada beberapa keuntungan pemanfaatan game bagi lingkungan belajar, antara lain: dapat memberikan motivasi dalam diri pada peserta didik, dalam beberapa kasus bahkan mendorong peserta didik untuk belajar, serta game membuat aktifitas belajar menjadi lebih menyenangkan.

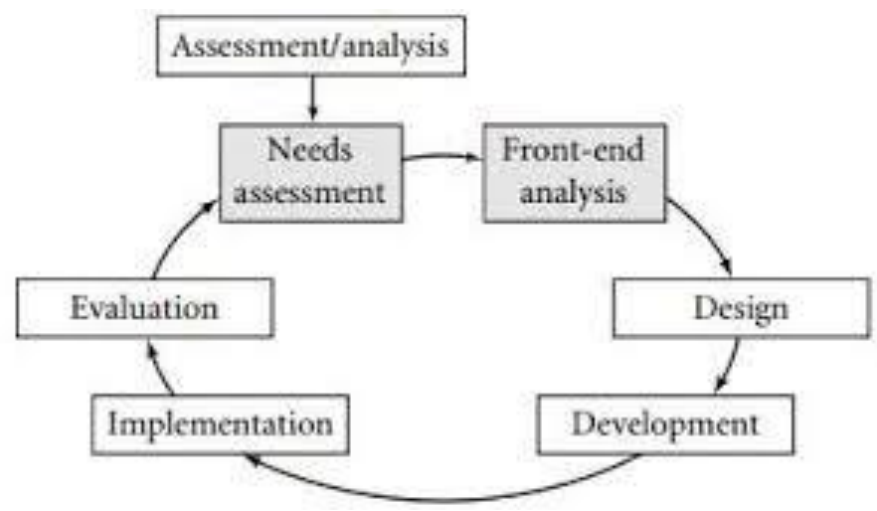

Gambar 1. Model Pengembangan Multimedia (Lee \& Owens, 2004) 
Model pengembangan yang digunakan pada penelitian pengembangan ini adalah model pengembangan Lee \& Owens (2004). Alasan pemilihan model tersebut menjadi acuan yaitu tahapan yang disampaikan dengan rinci dan lengkap. Langkah pengembangan model Lee \& Owens (2004) terdiri dari lima tahap, yaitu: 1) Assesment/analysis yaitu analisis kebutuhan, analisis awal \& akhir; 2) Design; 3) Development; 4) Implementation; 5) Evaluation.

\section{Need Assessment}

Tujuan tahapan need assessment adalah untuk memperoleh informasi kebutuhan-kebutuhan sebagai acuan atau landasan pengembangan media dalam aktifitas belajar mengajar. Hal pertama yaitu dengan melakukan observasi maupun wawancara guru dan beberapa siswa kelas VII di SMPN 2 Gurah. Hasil yang didapatkan dalam observasi bahwa metode yang digunakan adalah metode konvensional atau ceramah, diskusi dan eksperimen. Diketahui pula bahwa penyampaian materi memanfaatkan buku paket siswa kelas VII dan sesekali melakukan praktek atau eksperimen pada beberapa materi. Siswa mengaku merasa bosan dan jenuh dengan metode yang diterapakan guru.

\section{Front-end Analysis}

Tahap Front-end Analysis memiliki tujuan guna mendapatkan berbagai informasi secara detail mengenai produk/media yang dikembangkan. Tahap ini yaitu audience analysis, technology analysis, situation analysis, task analysis, crritical analysis, abjective analysis, issue analysis, media analysis, extant-data analysis dan cost analysis. Bertujuan menjadikan gambaran pelaksanaan langkah berikutnya. Tujuan aktifitas belajar dapat dirumuskan dan memperkecil hambatan saat mengimplementasikan produk/media yang diterapkan.

\section{Desain atau Perancangan}

Selanjutnya dalam tahap perancangan media pembelajaran, meliputi; a) menyesuaikan Kompetensi Inti (KI), Kompetensi Dasar (KD), dan Indikator; b) membuat flowchart; c) pembuatan storyboard media; d) memilih strategi pengujian dan menyusun tes; dan e) pengumpulan bahan-bahan yang diperlukan dalam pengembangan media.

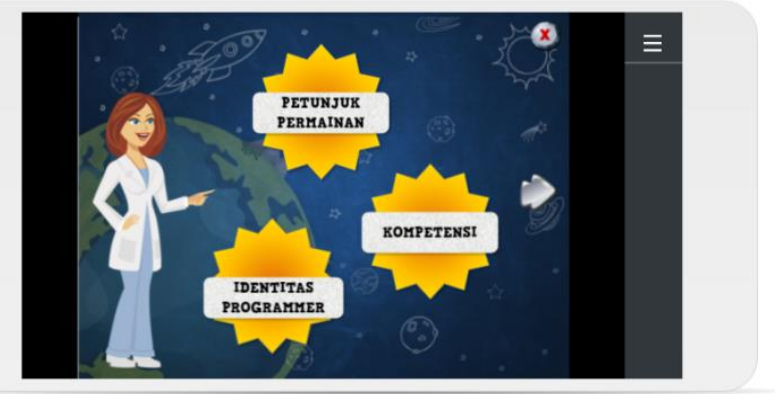

\section{Gambar 2. Tampilan Desain Menu Utama Game LABU}

\section{Development (Pengembangan) dan Implementasi (Penerapan)}

Dalam tahap pengembangan, menerapkan rancangan yang sudah dibuat sebelumnya dan membuat buku petunjuk pemakaian media guna mempermudah pebelajar dalam mengoperasikan media game LABU tersebut. Setelah media selesai dikembangkan, kemudian media dinilai oleh ahli media dan ahli materi sebelum diuji coba pada pebelajar. Angket respon ahli media terdiri dari 23 butir pernyataan dan ahli materi terdiri dari 13 butir penyataan, masing-masing ahli disesuaikan dengan media yang dikembangkan yaitu berupa game LABU.

Setelah media dinilai oleh para ahli, selanjutnya dilakukan uji coba oleh pebelajar. Uji coba dilakukan oleh 6 orang siswa dan dilaksanakan secara online dengan mengubah format media game LABU menjadi aplikasi (apk.) yang dapat dioperasikan menggunakan smartphone. Angket uji coba media oleh siswa terdiri dari 21 butir penyataan. Perolehan data bertujuan menganalisis tingkat kelayakan media game LABU yang dikembangkan. Selanjutnya, dilakukan tes hasil belajar siswa 
setelah menggunakan media game LABU dengan mengajukan 10 soal yang mengacu pada media yang dikembangkan.

\section{HASIL}

Berdasarkan beberapa kali uji coba media oleh ahli media, ahli materi dan uji coba oleh siswa terhadap media game LABU disajikan hasil apda grafik 1:

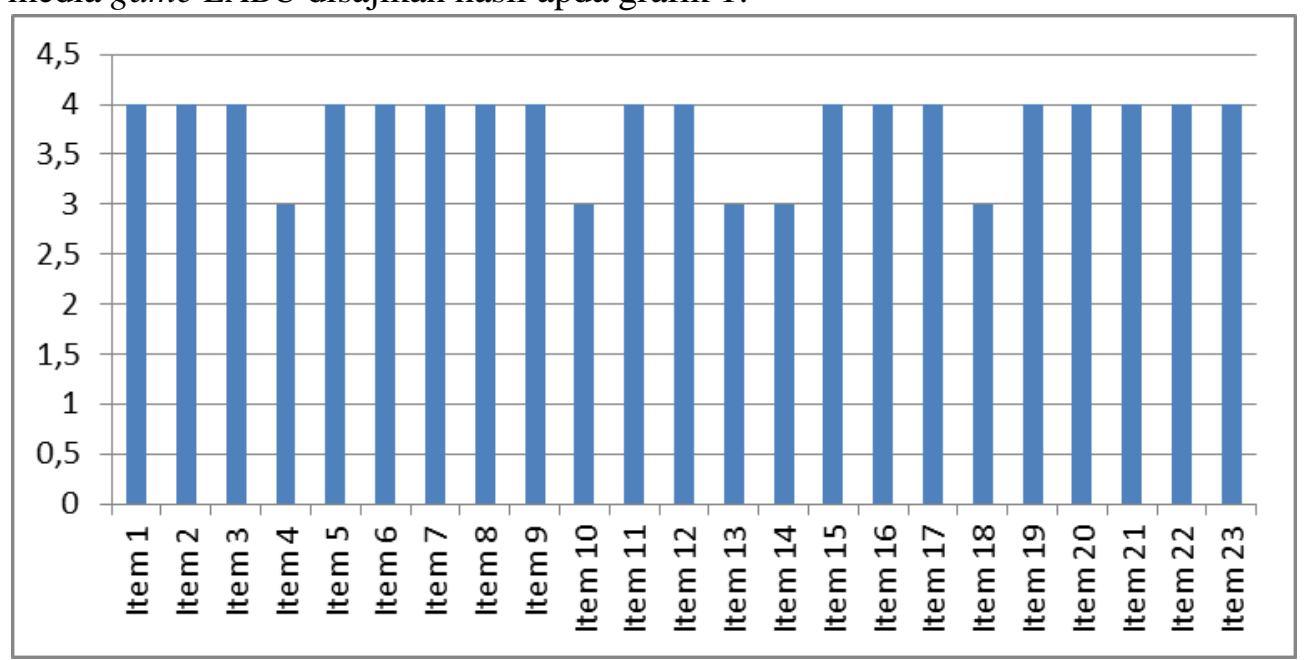

Grafik 1. Tanggapan Ahli Media

Berdasarkan angket respon ahli media pada grafik 1, disimpulkan bahwa produk yang dikembangkan berupa game LABU diperoleh rata-rata sebesar 3,78 dari 4,00 dan termasuk kategori layak. Pada angket ahli media terdapat 3 aspek yang dinilai antara lain; aspek tampilan, aspek penyajian, dan aspek pemrograman dengan 23 butir pernyataan. 18 butir pernyataan mendapat skor 4 dan 5 butir pernyataan mendapat skor 3. Ahli media juga memberikan saran dan komentar terhadap media yang dikembangkan.

Berdasarkan angket respon ahli materi pada grafik 2, disimpulkan bahwa produk yang dikembangkan diperoleh rata-rata sebesar 3,77 dari 4,00 dan termasuk kategori layak. Pada angket ahli materi terdapat 2 aspek yang dinilai antara lain; aspek pembelajaran dan aspek penyajian isi dengan 13 butir pernyataan. 10 butir pernyataan mendapat skor 4 dan 3 butir pernyataan mendapat skor 3 . Ahli materi memberikan komentar bahwa media sudah sesuai.

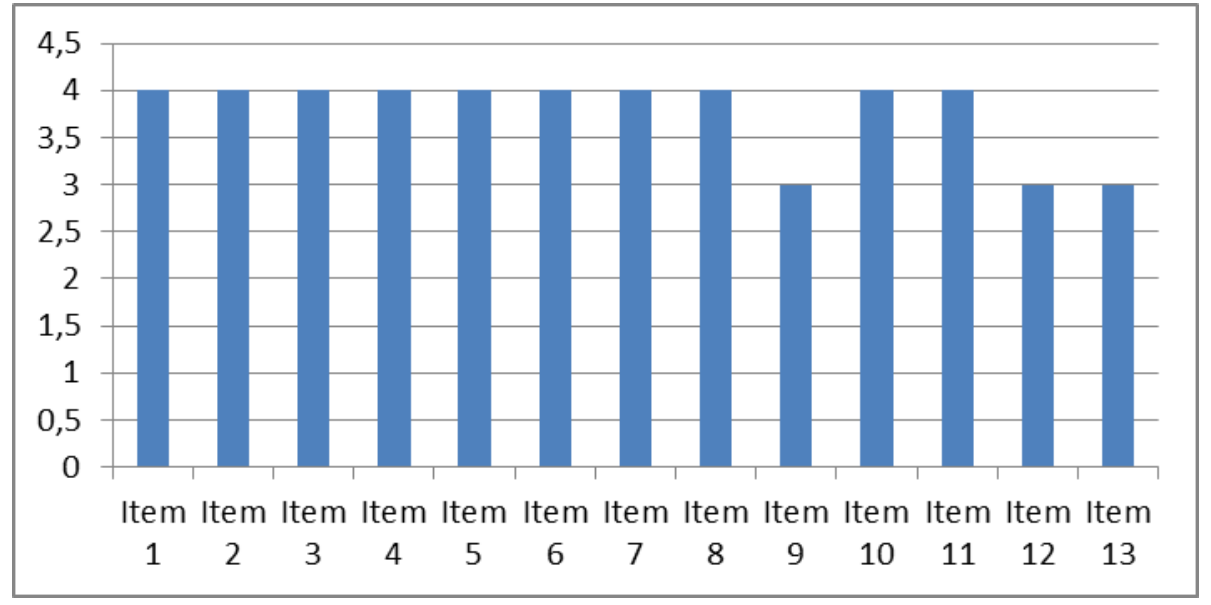

Grafik 2. Tanggapan oleh Ahli Materi

Dan selanjutnya dilakukan uji coba respon siswa terhadap produk yang dikembangkan, berdasarkan paparan pada grafik 3, disimpulkan bahwa produk yang dikembangkan diperoleh rata-rata sebesar 3,69 dari 4,00 dan termasuk kategori layak. Instrumen penilaian respon siswa terdiri dari 21 butir penyataan, memuat aspek tampilan dan aspek penyajian. 


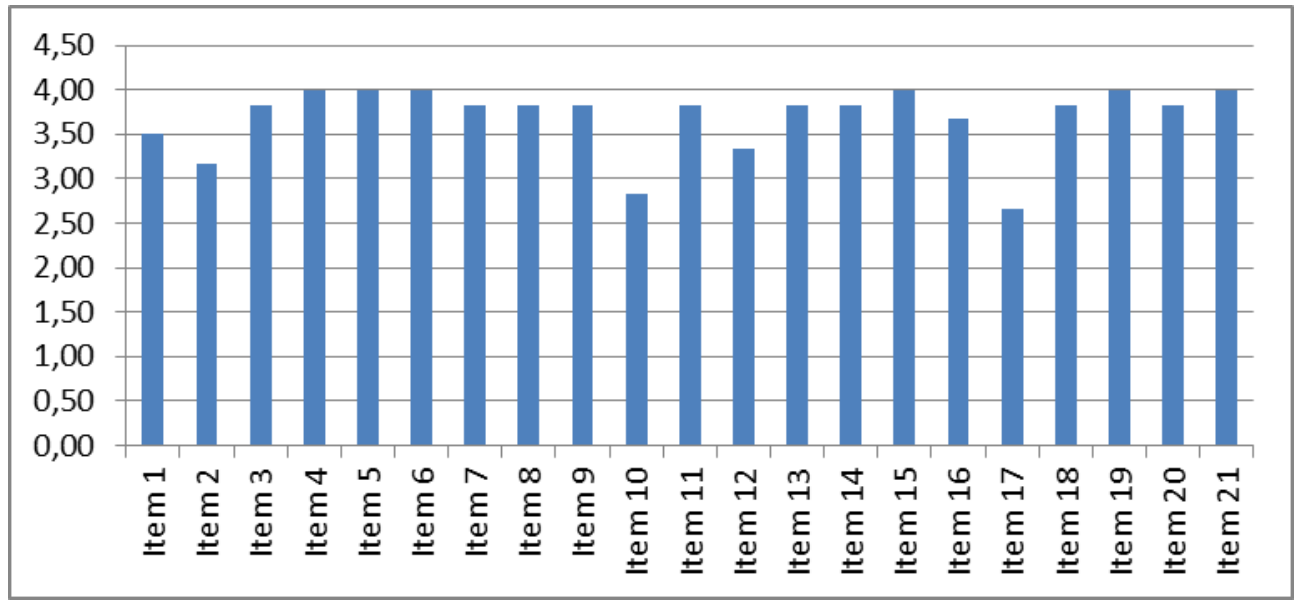

Grafik 3. Respon Siswa

\section{PEMBAHASAN}

Media game LABU yang dikembangkan menerapkan 6 elemen (Prensky, 2001). Pertama elemen aturan, aturan yang digunakan pada game untuk mencapai tujuan tertentu dan memastikan semua pengguna dapat memainkan game sesuai ketentuan yang dibuat. Dengan adanya aturan game LABU dapat digunakan lebih terarah dan terstruktur. Kedua elemen tujuan dan objek, pada game LABU yang dirancang memiliki tujuan tersendiri didalamnya dengan begitu pengguna paham tujuan yang ingin dicapai setelah menggunakan game LABU tersebut. Ketiga elemen outcomes dan umpan balik (feedback), digunakan untuk mengukur kemajuan pengguna terhadap tujuan permainan dan mengetahui apa yang baik atau kurang baik dari produk game LABU yang dihasilkannya. Keempat elemen tantangan atau level, tantangan membuat pengguna termotivasi untuk terus memainkan game LABU dan memecahkan tantangan yang ada disetiap tahapan / level. Terdapat 10 level untuk memacu motivasi siswa menggunakan game LABU. Kelima elemen interaksi, interaksi mempunyai dua aspek yang penting yaitu interaksi pengguna dengan komputer atau media dan interaksi pengguna dengan orang lain dengan tujuan dapat mendorong pengguna berdiskusi antar teman untuk memecahkan tantangan yang ada pada game LABU. Dan elemen yang terakhir adalah representasi atau cerita, hal ini dapat menarik perhatian pengguna untuk mengikuti alur cerita awal hingga akhir atau finish.

Selanjutnya produk game LABU dilakukan penilaian oleh ahli dan diuji coba kepada siswa yang melibatkan 6 orang siswa. Pada penelitian ini dilakukan saat pandemi covid-19 mulai menyebar di Indonesia dan mulai berlaku work form home bagi semua instansi termasuk pendidikan. Oleh karena itu pengambilan data dilakukan secara online melalui google form dan media yang dikembangkan diubah format menjadi aplikasi (.apk) yang dapat diakses melalui smartphone. Demikian dapat memudahkan pebelajar mengakses media game LABU kapanpun dan dimanapun dengan mudah tanpa harus menggunakan laptop atau komputer untuk menggunakannya. Dari hasil angket respon oleh ahli media mendapat nilai rata-rata sebesar 3,78 dengan 23 butir pernyataan. Poin terendah yang diperleh yaitu 3 dan poin nilai tertinggi yang diperoleh adalah 4 . Angket respon ahli media menunjukkan kategori layak digunakan dalam proses pembelajaran. Selain itu, ahli media memberikan kritik dan saran terkait aspek tampilan dan penyajian. Kritikan terhadap tampilan font yang kurang besar apabila dioperasikan menggunakan smartphone jadi perlu menyesuaian font yang digunakan. Dalam penyajian petunjuk permainan juga dirasa masih bertele-tele dan perlu dipersingkat. Pemilihan gambar dan animasi yang digunakan juga masih kurang menarik pengguna. Saran yang diberikan sebaiknya gunakan kalimat yang singkat, jelas dan mudah dipahami.

Setelah memperbaiki produk sesuai saran dan komentar ahli media, selanjutnya dilakukan penilaian oleh ahli materi. Dari hasil angket respon ahli materi mendapat rata-rata sebesar 3,77 dengan 13 butir penyataan. Hal itu menunjukkan bahwa produk yang dikembangkan dikategorikan layak 
digunakan dalam pembelajaran. Kemudian berdasarkan kritik dan saran dari ahli materi bahwa materi yang disajikan pada produk yang dikembangkan tersebut secara keseluruhan sudah jelas, serta media dapat mendorong siswa untuk bersifat aktif sesuai dengan kemampuan berfikir siswa dan tujuan pembelajaran. Multimedia game LABU mampu menjadikan siswa tertarik giat belajar dan mendorong untuk aktif dalam belajar mata pelajaran IPA. Materi yang disajikan pada multimedia game LABU sesuai dengan kompetensi dasar yang ingin dicapai. Multimedia game LABU berisikan teks, gambar, dan audio sehingga siswa termotivasi untuk menggunakan media tersebut. Bahasa yang digunakan komunikatif dan mudah dipahami sehingga informasi dan materi yang disampaikan lebih dipahami degan mudah. Kekurangan dari multimedia game LABU yang dikembangkan berupa sistematika penyajian yang terbatas dan tantangan yang disajikan perlu dikembangkan kembali. Setelah produk dilakukan beberapa perbaikan, ahli media menyatakan bahwa produk yang dikembangkan dapat diuji coba kepada siswa.

Selanjutnya dilakukan uji coba kepada siswa sebanyak 6 orang siswa kelas VII di SMPN 2 Gurah Kediri, secara keseluruhan rata-rata mendapat nilai sebesar 3,69 dari 21 butir pernyataan. Angket respon siswa memuat aspek tampilan dan aspek penyajian. Perolehan poin pada uji coba oleh siswa mendapat poin 4, 3 dan 2. Hal tersebut dapat dikatakan pebelajar tertarik terhadap multimedia game LABU yang dikembangkan. Melalui angket respon siswa, terdapat beberapa komentar yang diberikan bahwa dengan menggunakan multimedia game LABU memberikan suasana baru dalam belajar, meyenangkan, mudah memahami materi yang disampaikan, dan media yang dikembangkan sangat menarik. Sejalan dengan pernyataan Pramuditya \& Purwono (2018) dan pengembangan yang telah dilakukan sebelumnya oleh Putra, Soepriyanto dan Husna (2019) bahwa game menjadi salah satu solusi media belajar yang menyenangkan. Namun ada salah satu siswa memberikan komentar bahwa masih megalami kebingungan dalam memahami menggunakan game LABU yang dikembangkan tersebut. Kelebihan game saat digunakan dalam uji coba tersebut yaitu game mampu mendorong atau mengikat peserta didik untuk bermain lebih lama/menyelesaikan permainan, sehingga dapat mempertahankan perhatian lebih lama. Game juga mampu digunakan saat pembelajaran didalam kelas ataupun diluar kelas sehingga tidak terbatas pada penggunaanya. Multimedia game LABU juga bisa dijadikan alternatif dalam media pembelajaran di kelas. Menurut Asghari (2013) game edukasi memberikan pengaruh positif terhadap aktifitas belajar sebab permainan memberi pengalaman secara langsung dari pemakai atau pebelajar terkait. Berdasarkan tinjauan yang dilakukan McLaren (2017) dipaparkan bahwa aktifitas belajar lebih menarik dan pebelajar lebih memahami materi yang disampaikan setelah memakai media berupa game. Jadi pebelajar merasa senang dan termotivasi untuk giat belajar dengan memanfaatkan media berupa game LABU yang dikembangkan, selaras dengan pengembangan yang dilakukan seblumnya oleh Nuraeni, Soepriyanto dan Husna (2020).

Selanjutnya dilakukan tes setelah menggunakan media yang dikembangkan guna mengetahui ketercapaian media game LABU terhadap hasil belajar siswa. Dalam tes yang dilakukan terdapat 10 soal yang diajukan mengacu pada multimedia game LABU yang dikembangkan dengan poin tiap soal sebesar 10 poin. Hasil tes setelah menggunakan media yang dikembangkan diperoleh hasil diatas capaian rata-rata, yang menunjukkan bahwa media game LABU dapat dengan mudah dipahami siswa. Sejalan dengan pernyataan Sujalwo (2017) bahwa aktifitas belajar berbasis game cocok guna memaksimalkan motivasi belajar anak-anak, sebab terdapat tantangan yang harus dituntaskan sehingga memicu rasa keingintahuan dan motivasi yang semakin tinggi. Pada penelitian yang dilakukan Dewi dan Wibawa (2017) memaparkan bahwa menggunakan game dalam aktifitas belajar mengajar memberikan suasana yang menyenangkan, kreatif, dan meningkatkan hasil belajar siswa secara signifikan. Selanjutnya penelitian Rianingtias (2019) memaparkan bahwa pemanfaatan game sangat menarik dan unik dalam aktifitas belajar mengajar dan meningkatkan motivasi belajar siswa. Sejalan dengan pernyataan Prensky (2001) bahwa untuk meningkatkan motivasi siswa dapat menggunakan game digital. Penelitian yang dilakukan oleh Hermawan (2017) dan uji coba yang telah 
dilakukan terhadap pengembangan game untuk IPA oleh Hidayatulloh, Praherdhiono dan Wedi (2020) mengungkap bahwa pemanfaatan game dalam aktifitas belajar dapat meningkatkan hasil belajar siswa. Pengungkapan tersebut dapat diartikan bahwa game mampu meningkatkan hasil belajar pada dua mata pelajaran yang berbeda karakteristik.

Dalam penelitian ini produk dikembangkan berupa game LABU siswa kelas VII bertujuan meningkatkan kuantitas belajar siswa dan meningkatkan motivasi belajar siswa sehingga memperoleh hasil yang diinginkan dan ilmu yang diperoleh dapat menjadi dasar pemahaman ilmu pengetahuan dijenjang berikutnya. Media game LABU dapat menjadi variasi media belajar yang lebih menarik dan unik sehingga meningkatkan motivasi belajar siswa. Namun ada yang perlu diperbaiki kembali perihal konsep setiap level yang ditampilkan. Guna mengoptimalkan media pembelajaran berupa game LABU perlu adanya penelitian lebih lanjut dalam subjek uji coba yang lebih besar dan guru dapat memantau secara langsung. Sehingga diharapkan media pembelajaran yang dikembangkan dapat dimanfaatkan secara maksimal oleh seluruh siswa..

\section{SIMPULAN}

Berdasarkan penelitian yang telah dilakukan, game LABU menjadi salah satu inovasi pendidikan yang kreatif, menyenangkan, dapat meningkatkan hasil belajar siswa secara signifikan dan merangkum materi dalam sebuah permainan unik dan menarik sehingga memicu motivasi belajar siswa. Media game LABU menyajikan materi dengan variasi media audio maupun visual. Sesuai penelitian terdahulu memperoleh respon positif dan memperoleh kategori layak. Berdasarkan tanggapan ahli media, ahli materi dan tanggapan dari siswa terkait media game LABU memperoleh respon positif dan layak digunakan.

\section{DAFTAR RUJUKAN}

Asghari Nekah, S. M., Kalani, S., \& Ghanaee Chaman Abad, A. (2013). An introduction to designing educational-computer games with the linguistics approach in the area of disorders especially in learning. Exceptional Education Journal, 5(118), 36-48.

Baddeley, A. (2010). Working Memory. Current Biology, (Online), 20 (4): 136-140.

Bire, A. L., Geradus, U., \& Bire, J. (2014). Pengaruh gaya belajar visual, auditorial, dan kinestetik terhadap prestasi belajar siswa. Jurnal Kependidikan: Penelitian Inovasi Pembelajaran, 44(2).

Danim, S. (2008). Media Komunikasi Pendidikan Pelayanan Profesional Pembelajaran dan Mutu Hasil Belajar. Jakarta: PT. Bumi Aksara

Dasar, S., Handriyantini, E., Kom, S., \& Mt, M. (2009). Permainan Edukatif (Educational Games) Berbasis Komputer untuk Siswa Sekolah Dasar. June, 2015(9).

Dewi, D. A. P., Wibawa, \& Setya C. (2017). Pengembangan Game Edukasi "Krishna Adventure" dengan Metode Pembelajaran Menyenangkan (Joyful Learning). Jurnal IT-EDU, 2(1), 155-161.

Hakim, A. R., \& Windayana, H. (2016). Pengaruh Penggunaan Multimedia Interaktif Dalam Pembelajaran Matematika Untuk Meningkatkan Hasil Belajar Siswa SD. EduHumanioral Jurnal Pendidikan Dasar Kampus Cibiru, 4(2).

Hermawan, D. P. (2017). Efektivitas Penggunaan game edukasi berjenis puzzle, RPG dan Puzzle RPG sebagai sarana belajar matematika. Surabaya:Institut Teknologi Sepuluh Nopember.

Hidayatulloh, S., Praherdhiono, H., \& Wedi, A. (2020). Pengaruh Game Pembelajaran Terhadap Peningkatan Hasil Belajar Pemahaman Ilmu Pengetahuan Alam. Jurnal Kajian Teknologi Pendidikan, 3(2), 199-206.

Hurd, Daniel dan Jenuings, Erin. 2009. "Standardized Educational Games Ratings: Suggested Criteria “. Karya Tulis Ilmiah

Lee, W. W., \& Owens, D. L. (2004). Multimedia-based instructional design: computer-based training, web-based training, distance broadcast training, performance-based solutions. John Wiley \& Sons 
McLaren, B. M., Adams, D. M., Mayer, R. E., \& Forlizzi, J. (2017). A computer-based game that promotes mathematics learning more than a conventional approach. International Journal of Game-Based Learning (IJGBL), 7(1), 36-56.

Melero, J., Leo, H., \& Davinia. (2014). A Model for the Design of Puzzle-Based Games Including Virtual and Physical Objects. International Forum of Educational Technology \& Society, 17(3), 192-207.

Munir. (2013). Multimedia dan Konsep Aplikasi dalam Pendidikan. Bandung: Alfabeta

Nuraeni, E. T., Soepriyanto, Y., \& Husna, A. (2020). Role Playing Game Periodisasi Zaman Praaksara sebagai Multimedia Pembelajaran Sejarah untuk Siswa Sekolah Menengah Pertama. Jurnal Kajian Teknologi Pendidikan, 3(3), 340-349.

Pramuditya, S. A., Noto, M. S., \& Purwono, H. (2018). Desain Game Edukasi Berbasis Android pada Materi Logika Matematika. JNPM (Jurnal Nasional Pendidikan Matematika), 2(2), 165-179.

Prensky, M. (2001). Fun, Play and Games: What Makes Games Engaging. Digital game-based learning, 5(1), 5-31.

Putra, A. P., Soepriyanto, Y., \& Husna, A. (2019). Pengembangan multimedia game edukasi tentang keragaman masakan khas daerah-daerah di indonesia untuk kelas v sd. Jurnal Kajian Teknologi Pendidikan, 1(4), 299-306.

Ramadhan, H. F., Sitorus, S. H., \& Rahmayuda, S. (2019). Game Edukasi Pengenalan Budaya dan Wisata Kalimantan Barat Menggunakan Metdoe Finite State Machine Berbasis Android. Coding Jurnal Komputer dan Aplikasi, 7(01).

Rianingtias, Okta. (2019). Pengembangan Game Edukasi Berbasis Android Sebagai Media Pembelajaran Biologi Bernuansa Motivasi Siswa Kelas XI di SMA/MA. Lampung: Fakultas Tarbiyah dan Keguruan.

Rohwati, M. (2012). Penggunaan Education Game untuk Meningkatkan Hasil Belajar IPA Biologi Konsep Klasifikasi Makhluk Hidup. Jurnal Pendidikan IPA Indonesia, 1(1), 75-81.

Royle, K. (2008). Game-based learning: A different perspective. Innovate: Journal of Online Education, 4(4).

Samsul, A. H. (2016). Game Edukasi Cepat Tepat Dengan Metode Finite State Machine (Fsm) Pada Smartphone. Malang: Universitas Islam Negeri Maulana Malik Ibrahim.

Sujalwo, S., \& Sukirman, S. (2017). Pengembangan Game Berbasis Komputer sebagai Media Pembelajaran IPA Terpadu Kelas VIII SMP. Manajemen Pendidikan, 12(3), 239-247.

Surahman, E., \& Surjono, H., D. (2017). Pengembangan Adaptive Mobile Learning Pada Mata Pelajaran Biologi SMA Sebagai Upaya Mendukung Proses Blended Learning. Jurnal Inovasi Teknologi Pendidikan. 4(1), 26-37

Surahman, E., \& Alfindasari, D. (2017, September). Developing adaptive mobile learning with the principle of coherence Mayer on biology subjects of high school to support the open and distance education. In 3rd International Conference on Education and Training (ICET 2017) (pp. 184-190). Atlantis Press.

Wolf. (2000). Genre and the Video Game (chapter 6 of the medium of the video game)

Wulandari, R., Susilo, H., \& Kuswandi, D. (2016). Multimedia Interaktif Bermuatan Game Edukasi Sebagai Salah Satu Alternatif Pembelajaran IPA di Sekolah Dasar. Jurnal Pendidikan, 1-7. 